\title{
Continental Portuguese Territory Flood Susceptibility Index - contribution to a vulnerability index
}

\author{
R. Jacinto ${ }^{1, *}$, N. Grosso ${ }^{2,}$, E. Reis ${ }^{1}$, L. Dias ${ }^{2}$, F. D. Santos ${ }^{2}$, and P. Garrett ${ }^{2}$ \\ ${ }^{1}$ Centre for Geographical Studies, IGOT, Edificio da Faculdade de Letras da Universidade de Lisboa, University of Lisbon, \\ Alameda da Universidade, 1600-214 Lisbon, Portugal \\ ${ }^{2} \mathrm{CE} 3 \mathrm{C}$ - Centre for Ecology, Evolution and Environmental Changes, Faculdade de Ciências, Universidade de Lisboa, \\ 1749-016 Lisbon, Portugal \\ *These authors contributed equally to this work.
}

Correspondence to: R. Jacinto (jacinto.rita@gmail.com)

Received: 13 November 2014 - Published in Nat. Hazards Earth Syst. Sci. Discuss.: 15 December 2014

Accepted: 13 July 2015 - Published: 26 August 2015

\begin{abstract}
This work defines a national flood susceptibility index for the Portuguese continental territory, by proposing the aggregation of different variables which represent natural conditions for permeability, runoff and accumulation. This index is part of the national vulnerability index developed in the scope of Flood Maps in Climate Change Scenarios (CIRAC) project, supported by the Portuguese Association of Insurers (APS).

This approach expands on previous works by trying to bridge the gap between different flood mechanisms (e.g. progressive and flash floods) occurring at different spatial scales in the Portuguese territory through (a) selecting homogeneously processed data sets and (b) aggregating their values to better translate the spatially continuous and cumulative influence in floods at multiple spatial scales.

Results show a good ability to capture, in the higher susceptibility classes, different flood types: fluvial floods and flash floods. Lower values are usually related to mountainous areas, low water accumulation potential and more permeable soils. Validation with independent flood data sets confirmed these index characteristics, although some overestimation can be seen in the southern region of Alentejo where, due to a dense hydrographic network and an overall low slope, floods are not as frequent as a result of lower precipitation mean values.

Future work will focus on (i) including extreme precipitation data sets to represent the triggering factor, (ii) improving representation of smaller and stepper basins, (iii) optimizing
\end{abstract}

variable weight definition process and (iii) developing more robust independent flood validation data sets.

\section{Introduction}

Hydro-meteorological events such as floods and storms are the most frequent natural disasters in Europe (IPCC, 2012), responsible for two-thirds of the damage and costs associated with all types of natural disasters (EEA, 2012b). Those costs have been growing since 1980, as a result of human activities and the increasing severity and frequency of floods (EEA, 2012b). Flood frequency and severity are expected to continue increasing due to climate change, even in regions like Portugal, where mean annual rainfall will probably decrease (EEA, 2012b; IPCC, 2012).

In Portugal the growing concentration of people and activities along with soil impermeabilization, especially in urban areas, are responsible for a current increase in flood hazard and losses (Quaresma, 2008; EEA, 2012a; Jacinto et al., 2013). At the same time, the 100-year return period flood discharge maximum level and consequent flood-related losses are expect to further intensify, until the end of the century, under climate change scenarios, when compared to the 19611990 period (EEA, 2012b). For example, several Portuguese cities with more 10000 inhabitants are estimated to have more than $10 \%$ of their area flooded if the rivers rise $1 \mathrm{~m}$ (EEA, 2012a). 
The focus of this work will be on susceptibility to floods, for the Portuguese continental territory, which is defined as the propensity of an area to be affected by floods. This propensity is given by the territory intrinsic characteristics such has slope, geology, river network, and land use. The present work is part of a flood vulnerability study for the Portuguese continental territory, developed in the Flood Risk Mapping in Climate Change Scenarios (CIRAC) project.

Section 2 presents a state-of-the-art review of concepts and methods implemented to translate flood susceptibility and its relation with flood vulnerability and provides insight on the current work contribution to improve flood susceptibility mapping at the national scale. Section 3 is divided into three subsections describing the study area hydromorphological characteristics, the different data sets used and the methodology followed to design and implement the national susceptibility index map. Section 4 presents the main results, including intermediate and final index maps, provides a first overall interpretation of their advantages and limitations and validates them through a comparison with historical flood events. Finally, Sect. 5 analyses the main findings, the contributions to the state of the art and the impact of the results in the Portuguese context.

\subsection{State of the art}

The crucial factor on turning a flood on a potential damaging event for communities and ecosystems is the proximity to prone areas such as floodplains, which determines their vulnerability to the phenomena (Cutter et al., 2008). The IPCC (2012) presented vulnerability as being the "predisposition, susceptibilities, fragilities, weaknesses, deficiencies, or lack of capacities that favour adverse effects on the exposed elements". This is a general concept that introduces susceptibility as one of the different dimensions that contribute to and should be contained in a vulnerability assessment, as illustrated in Fig. 1. Adger (2006) also relates both concepts by defining vulnerability as the susceptibility to harm from exposure to a change in the environment or in the society and the incapacity to adapt to those changes. The juxtaposition and interdependency between vulnerability and susceptibility is evident, leading sometimes to inconsistencies in their definition, depending on the researching perspective.

For instance, according to Balica et al. (2012), "a system is susceptible to floods due to exposure in conjunction with its capacity/ incapacity to be resilient, to cope, recover or adapt to". The authors connected susceptibility with exposure, considered as the hydro-geological component, and also with the institutional and socio-economic systems.

Collier and Fox (2003), despite not discussing directly the susceptibility concept, identified some components to describe a baseline susceptibility to flash floods that were mostly derived from inherent characteristics of a specific basin. Those characteristics are the likelihood of unimpeded

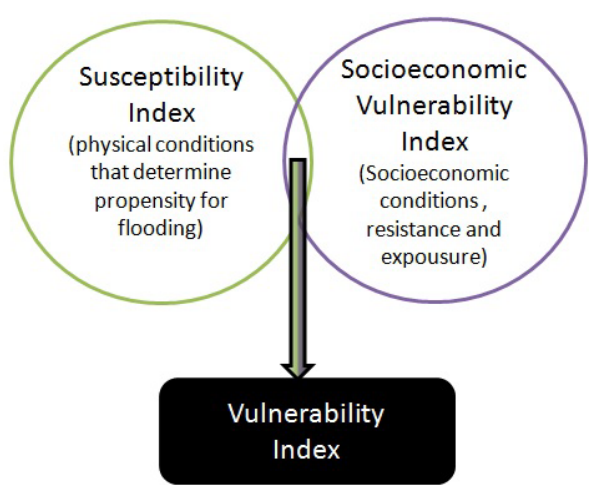

Figure 1. Components of a vulnerability index.

flow and the existence of channel constrictions, catchment slope, ratio of catchment area to mean drainage path length, and ratio of land use to vegetation type as a proxy of urban extension. This approach to susceptibility leads to the definition adopted in this work and also identified in other studies (Verde and Zêzere, 2007; Zêzere et al., 2005), where flooding susceptibility is a characteristic of an area given by its natural terrain configuration and occupation and that determines its propensity to flooding.

The several steps included in the methodological approach to susceptibility estimation, from variable and source data selection, to the composition of indicators, depend not only on the chosen definition of susceptibility but also on the spatial scale of analysis. National assessments are usually designed to provide a high-level picture of flood susceptibility and are unable to represent in a consistent manner the different flooding mechanisms (e.g. urban flash floods versus fluvial floods). For instance, when working susceptibility mapping at European level, De Roo et al. (2007) and Marchi et al. (2010) used topography to characterize the flooding phenomena. They used SRTM-3 (De Roo et al., 2007) combined with other generalizable topographic factors such as catchment slope, the ratio between the catchment area and the mean drainage path length (Marchi et al., 2010). In contrast, at the watershed scale, a wider range of site-specific data and indicators can be used, like the ones selected by Yahaya et al. (2010) and Santangelo et al. (2011), with several data sources like precipitation, river network, slope, soil type and land use: this allows for a better characterization of the flooding phenomena in that basin but hinders the generalization of the methodology to other areas. Scale is, therefore, a determinant factor on variable selection. When the territory is larger, the short number and simplicity of variables prevail, since it is more difficult to have the same kind of data in the whole territory, but also because some variables might not make sense on such a scale due to the generalization or territorial asymmetries (e.g. precipitation in mainland Portugal presents a great contrast north and south Tagus river). 
There are limited academic works on flood vulnerability or susceptibility evaluation in Portugal. Sá and Vicêncio (2011) presented an approach for mapping flood risk and vulnerability for each municipality of the Portuguese continental territory, using information on the 100 -year return period precipitation for each district (group of municipalities), urban land use percentage for each municipality (obtained from Corine Land Cover data), mean number of floods registered by the National Civil Protection Authority (ANPC), river length (in $\mathrm{km}$ ) compared to the area of the municipality and the number of inhabitants in each municipality. Other academic work, for smaller study areas, analysed the vulnerability to floods in Águeda Municipality and used the floodable areas of the National Ecologic Reserve to represent susceptibility to floods (Figueiredo et al., 2009).

The work presented here contributes to the improvement of the current state of the art in the susceptibility evaluation field by designing and implementing, for the first time, a flood susceptibility index for the Portuguese territory. Some innovative methodological features are also introduced to overcome the limitations stated above, regarding the determination of flood susceptibility at a national scale. Variable selection tries to reflect the different flood dynamics that occur in the Portuguese territory. Selected parameters include flow accumulation potential, topographical and land use/soil permeability characteristics, representative of processes at different scales and influent in both progressive and flash floods. The selection process also reflects the need to reduce index complexity by choosing fewer input variables and select data sets that are uniformly processed across the Portuguese territory, to minimize index misinterpretation due to possible spatial inconsistencies at a country scale. The exclusion of precipitation reflects a focus on the territory characteristics as well as the difficulty of having a data set that could efficiently represent the reality and not hide the susceptibility in the Alentejo and Algarve regions, both located in the south of Tagus River where the mean annual precipitation is much less than northern Tagus River, which is less affected by frontal systems than the north. The inclusion of precipitation would require a different scale of analysis, namely a regional index. Also, there is a double evaluation for types of episodes and events, extreme rainfall and annual mean rainfall. Finally, the presented methodology applies an aggregation methodology to some of the chosen variables, described in more detail in Sect. 1.2.3, to better represent the spatially continuous and cumulative nature of their influence in flood-generating mechanisms, across increasingly higher spatial scales.

\subsection{Materials and methods}

\subsubsection{Study area}

The study area is the continental Portuguese territory, as illustrated in Fig. 2a, part of the Iberian Peninsula, located in the southwest of Europe.

Historically, and due to climatic characteristics, this territory has frequently registered flood occurrences. According to Quaresma (2008), during the period between 1900 and 2006, the annual average of hydro-geomorphological occurrences with losses in the Portuguese continental territory has been growing. For a similar period (1900-2008), Quaresma and Zêzere (2011) concluded that $82 \%$ of the hydro-geomorphological events in mainland Portugal were floods.

In mainland Portugal different kinds of hydrologic extreme events occur, varying from those with slow spreading and large duration, normally extending to large areas (socalled fluvial floods), and those with very fast spreading, short duration and concentrated impact (flash flood events) (Ramos and Reis, 2001, 2002). The flash flood events occur mainly on small watersheds or in urban areas and the fluvial floods occur usually at a larger scale such as the Tagus, Guadiana, Mondego and Douro basins, as illustrated in Fig. 2 b. The topography of the Portuguese territory is steeper to the north of the Tagus River and flatter in the south, especially in Alentejo region, between the rivers Tagus and Mira, as illustrated in Fig. 2c.

\subsubsection{Data sets}

The Hydrosheds (Hydrological data and maps based on Shuttle Elevation Derivatives at multiple Scales) digital elevation model (DEM) was used to obtain two of the three final variables and several other auxiliary variables. Hydrosheds data are derived from the Shuttle Radar Topography Mission (SRTM) at 3 arcsec resolution $(90 \mathrm{~m})$ and are freely available online (http://hydrosheds.cr.usgs.gov). The original data have been hydrologically conditioned in order to be used in regional and global watershed analysis. Furthermore it has an adequate scale for country-scale flood susceptibility analysis, allowing for a homogeneous and spatially continuous processing of the different data sets. The Hydrosheds DEM was used to derive slope, flow accumulation and direction and the hydrographic network. All original and subsequently processed data sets were converted to the WGS84 coordinate system and resampled to a $90 \mathrm{~m}$ resolution grid.

Flow accumulation shows the accumulation paths and the amount of cells in the entire basin that contribute to the flow on a specific cell. In the case of an international river, this variable accounts for both the Portuguese and international parts of the basin. It represents the drainage network and its water accumulation potential. Therefore, an increase in flow accumulation should reflect an increase in flood susceptibil- 


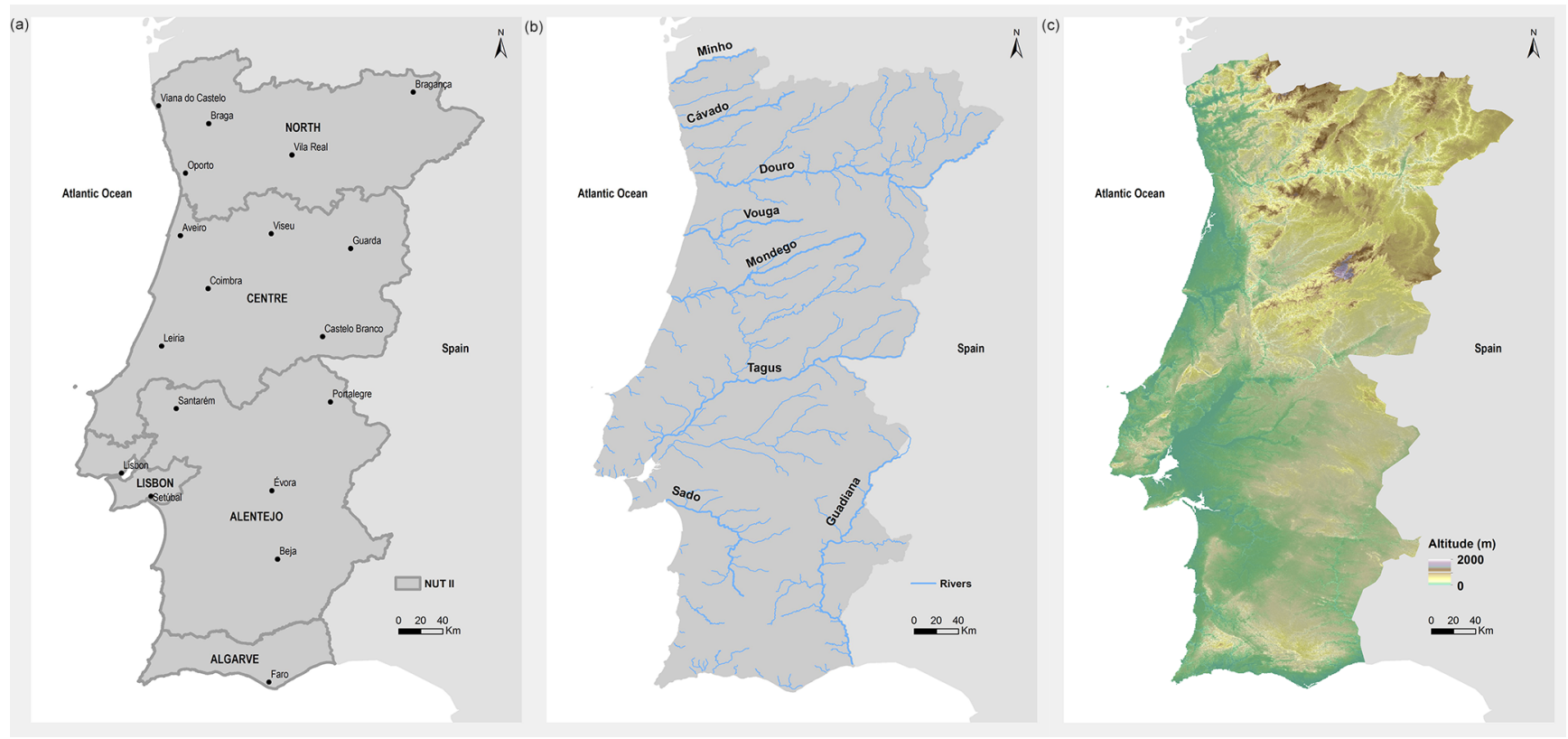

Figure 2. Characterization of the study area - Portuguese regions and main cities (a), Portuguese mainland main river network (b), and altitude (c).

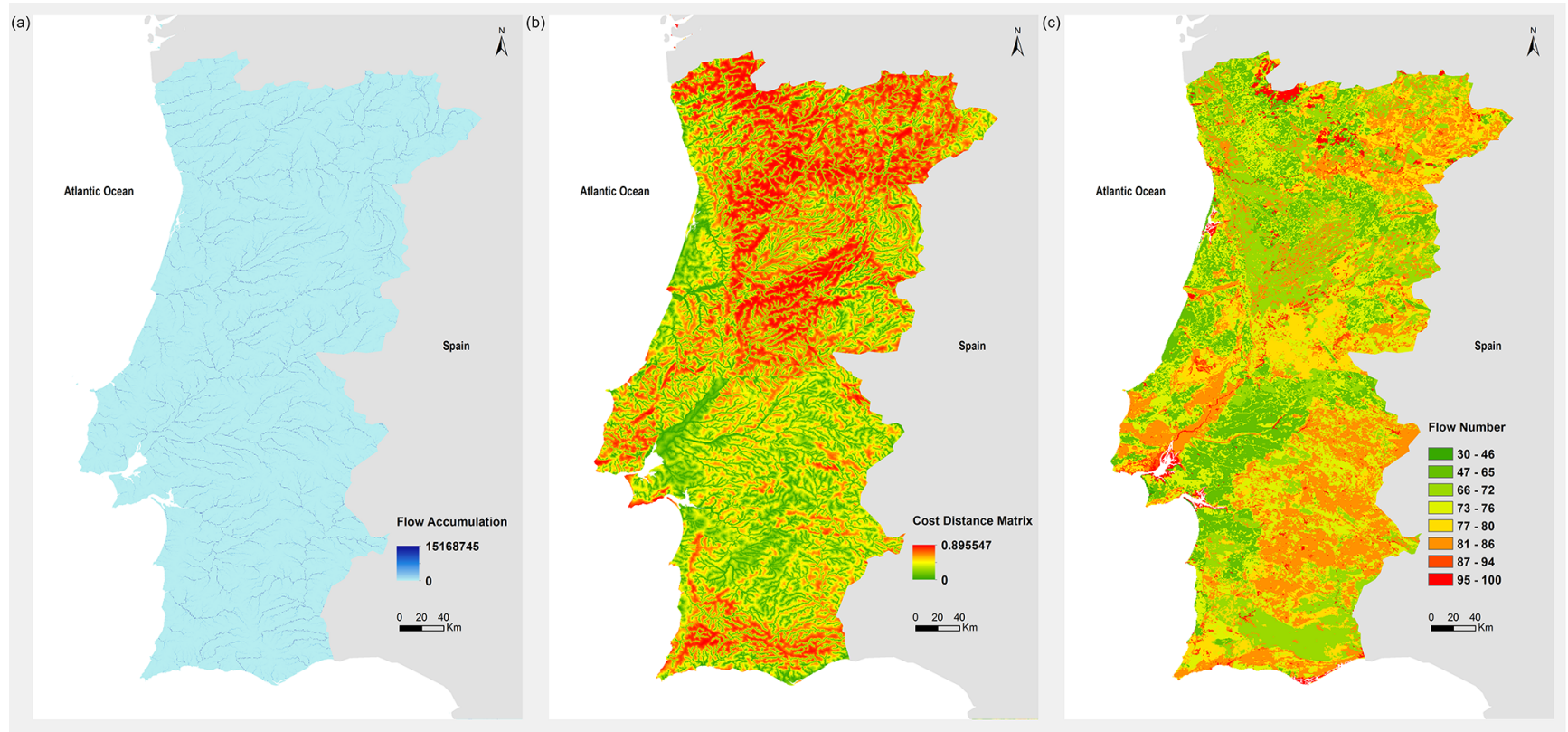

Figure 3. Maps of the original variables used in the flood susceptibility index: (a) flow accumulation, (b) cost distance matrix, and (c) flow number.

ity (Lehner et al., 2008). Accumulation values are representative of the entire territory and although represented by a spatially continuous grid, the range of values is very wide, making the small rivers visually imperceptible, due to their small flow accumulation values when compared with the bigger ones such as Tagus, Douro or Guadiana rivers, as illustrated in Fig. 3a. For this reason this variable is more repre- sentative of flood events associated with fluvial floods in the main Portuguese rivers.

The cost distance matrix, Fig. 3a, was obtained using the cost distance ArcGIS tool, based on the hydrography and slope themes. It represents the topographic resistance to water lateral movements associated with overflow processes during floods and inundations and also identifies more flood- 
Table 1. Information summary for all used data sets.

\begin{tabular}{|c|c|c|c|}
\hline Variable & Source & $\begin{array}{l}\text { Original spatial } \\
\text { resolution }\end{array}$ & Role in index calculation \\
\hline \multicolumn{4}{|c|}{ Auxiliary variables } \\
\hline DEM & $\begin{array}{l}\text { Hydrosheds website } \\
\text { (http://hydrosheds.cr.usgs.gov/) }\end{array}$ & $3 \operatorname{arcsec}(\approx 90 \mathrm{~m})$ & $\begin{array}{l}\text { Auxiliary variable to calculate } \\
\text { the slope theme. }\end{array}$ \\
\hline Slope & $\begin{array}{l}\text { Calculated based on the } \\
\text { Hydrosheds DEM }\end{array}$ & $3 \operatorname{arcsec}(\approx 90 \mathrm{~m})$ & $\begin{array}{l}\text { Auxiliary variable to calculate flow } \\
\text { direction and accumulation, } \\
\text { hydrography }\end{array}$ \\
\hline Flow direction & Calculated based on the slope & $3 \operatorname{arcsec}(\approx 90 \mathrm{~m})$ & $\begin{array}{l}\text { Auxiliary variable used to define the hy- } \\
\text { drography and flow accumulation }\end{array}$ \\
\hline Hydrography & Calculated based on flow direction & $3 \operatorname{arcsec}(\approx 90 \mathrm{~m})$ & $\begin{array}{l}\text { Auxiliary variable used to define the } \\
\text { cost distance }\end{array}$ \\
\hline \multicolumn{4}{|c|}{ Main variables used in flood susceptibility index } \\
\hline Flow accumulation & $\begin{array}{l}\text { Derived from the Hydrosheds DEM and } \\
\text { flow direction themes }\end{array}$ & $3 \operatorname{arcsec}$ & Definition of water accumulation areas \\
\hline Cost distance & $\begin{array}{l}\text { Derived from the hydrography and } \\
\text { slope themes }\end{array}$ & $3 \operatorname{arcsec}$ & $\begin{array}{l}\text { Difficulty associated with water lateral } \\
\text { movements in overflow processes }\end{array}$ \\
\hline Flow number & $\begin{array}{l}\text { Portuguese Water Atlas } \\
\text { (http://geo.snirh.pt/AtlasAgua/) }\end{array}$ & $500 \mathrm{~m}$ & Soil permeability \\
\hline
\end{tabular}

prone accumulation areas in the proximity of water courses. The cost value is calculated for each $90 \mathrm{~m}$ cell based on two factors: (a) the original slope and (b) the distance to the drainage network derived from Hydrosheds. It varies between 0 and 1 , where lower cost distance can be found in flat areas, closer to the water courses values, corresponding to areas with higher susceptibility to be flooded. The resulting matrix complements the information given by flow accumulation, since it locates potential water accumulation areas in the regions contiguous to the drainage network. Lower cost distance values, corresponding to flat areas, can be found, for instance, in the region between the Tagus River and Algarve region (Alentejo) as well as the occidental coastal part of the territory. In the specific case of the Alentejo region there is an apparent disagreement between the relatively sparse hydrographic network represented in Fig. 3a and the high frequency of low cost distance values. This is due to the presence of a numerous impermanent rivers in the drainage network map derived from DEM information, when compared with the permanent river network.

The flow number data set for the national territory was collected from the Water Atlas online, made available by the Portuguese Water Institute (http://geo.snirh.pt/AtlasAgua/). It was produced by the Portuguese Environment Institute, based on two maps:

1. the hydrological soil type divided into four classes (A, B, C and D), according to the Soil Conservation Service classification, with increasing capacity to generate superficial flow (United States Soil Conservation Service - USSCS, 1986);
2. the Corine Land Cover 2000 (CLC2000) map (Instituto do Ambiente, 2005).

The final flow number map, Fig. 3c, was determined, following the work done by Lobo-Ferreira (1995), based on a reclassification that combines the two parameters. Further details on the production of this theme are given on the Water Atlas website (http://geo.snirh.pt/AtlasAgua/download/ ProducaoNumerosEscoamento.pdf). The values are dimensionless and range from 59 to 100 , with higher values corresponding to higher soil permeability. This variable is representative of conditions at smaller local scale and is particularly important to translate, for instance, the higher superficial flow generation potential in urban impermeabilized areas.

The Portuguese Water Atlas also provided (a) inundated area maps for the 100-year return period flood for some of the main Portuguese rivers (e.g. Tagus, Mondego, Sado, Zêzere and Vouga) and (b) a flood occurrence point map, produced by the Water Institute, based on events registered by the National Civil Protection Association (ANPC) and on information gathered from periodic journals, which are shown in Fig. 4a.

The first was used to adjust the final index composition based on different variable weights and to help define the interval range of each final susceptibility class. The second was used to validate the index results, together with a database, provided by Quaresma (2008), containing the number of events with considerable damage per municipality that occurred in the last century, as illustrated in Fig. 4b. 

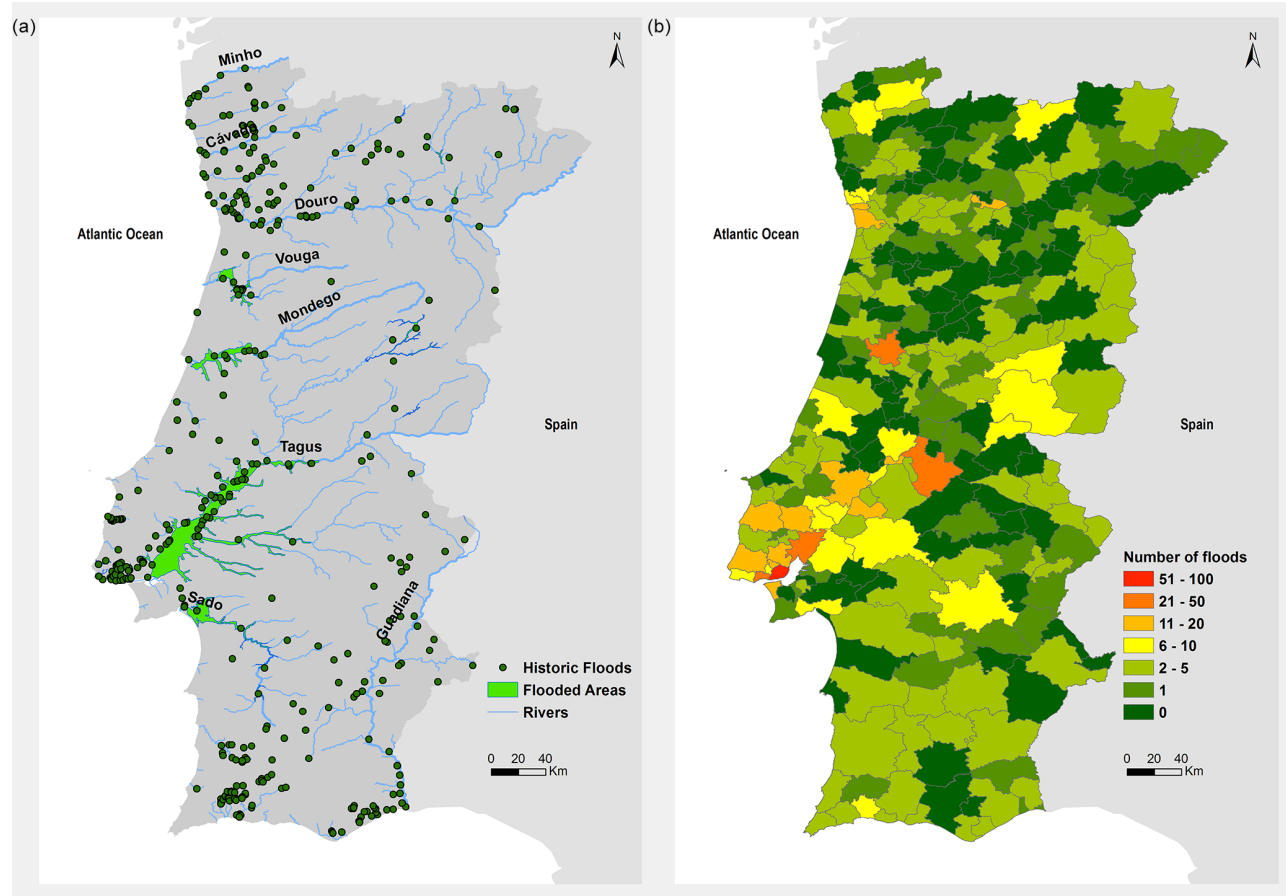

Figure 4. External flood data sets used in this work: (a) inundated area for the 100-year return period flood in the main Portuguese rivers and flood historical points based on civil protection registries and information from journals; (b) number of occurrences with considerable damage per municipality that occurred in the last century (adapted from Quaresma, 2008).

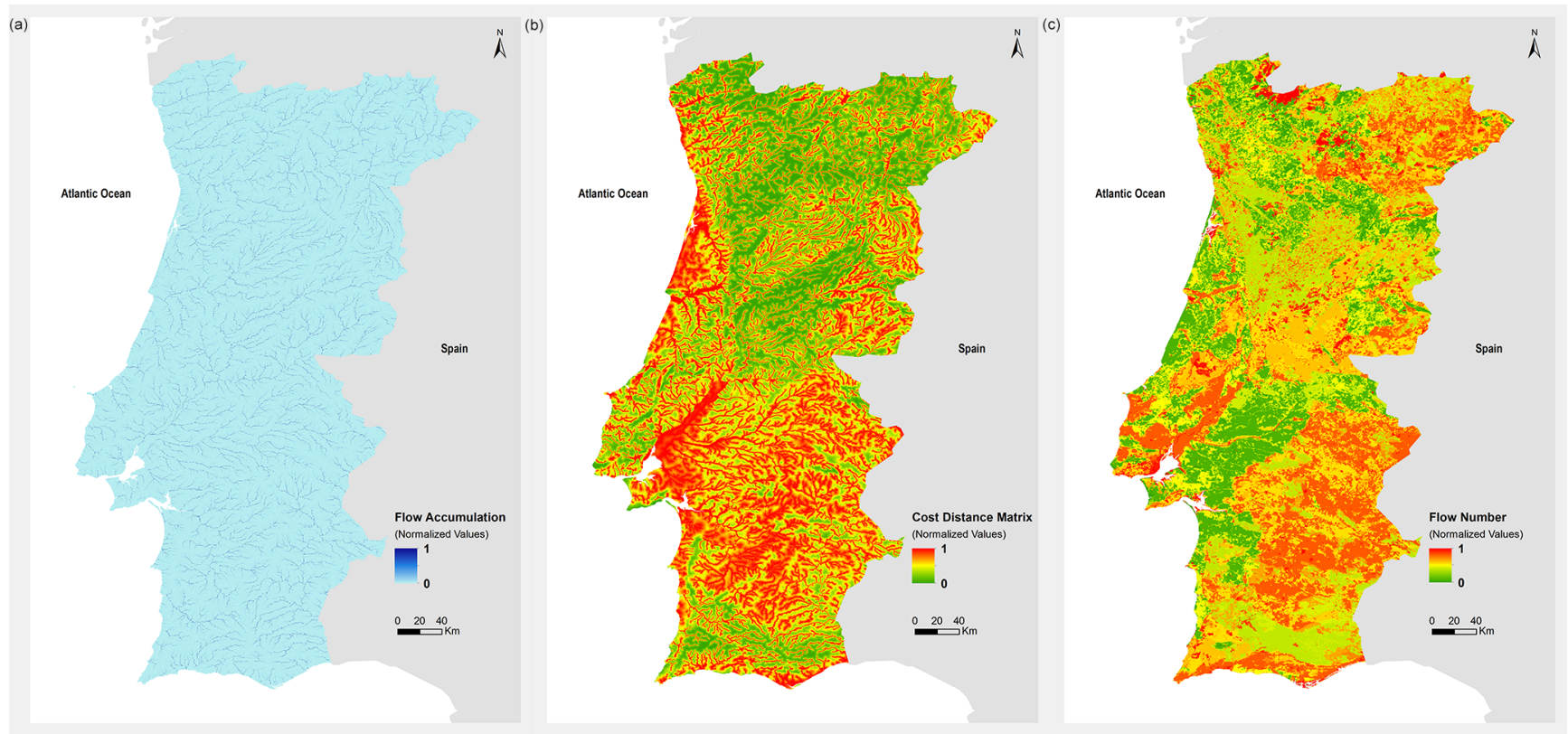

Figure 5. Normalized variables used in the flood susceptibility index: (a) flow accumulation, (b) cost distance matrix and (c) flow number.

Table 1 summarizes all information regarding the different data sets used in this work.

A decision was made not to include a precipitation data set in the index formulation since its purpose was to reflect only the terrain morphological characteristics that in- fluence flood susceptibility, regardless of the magnitude and spatiotemporal variation of flood triggering factors. This also allows the possibility of including, on a later stage, a precipitation theme or a combination of precipitation themes, like the mean annual precipitation or a set of maps with the inter- 
polated ground station precipitation for different return periods and durations (Brandão et al., 2001) to better reflect flood susceptibility for any specific climatological time period.

\subsubsection{Methods}

The main objective of the methodology presented in this section is to produce, using the above described data sets, a spatially continuous flood susceptibility index for the Portuguese territory, varying from 0 to 1 , where the highest values correspond to a higher flood propensity. To achieve this, a four-stage approach was followed, including the following:

a. an aggregation process for the flow number data set to better represent, for each cell, the cumulative influence of its upstream to downstream spatial distribution;

b. a normalization process for all variables to rescale them to common 0 to 1 range, where higher values represent areas more susceptible to floods, shown in Fig. 5;

c. an expert-analysis-based variable weight definition technique to establish the importance of each individual variable in the final index;

d. the definition of four susceptibility classes by comparison with inundated areas maps developed for the Portuguese main rivers and urban areas; and

e. an index validation procedure by comparison with other independent flood data sets.

The first methodological phase corresponded to one of the main innovative aspects of this work: the application, for the entire Portuguese continental territory, of a variable spatial aggregation method, based on the one developed by Reis (2011) and already implemented for basin-scale studies in regional (e.g. Ramos et al., 2009, 2010) and municipal (e.g. Ascenso, 2011) contexts. This approach improves substantially the depiction of the cumulative nature of the flooding phenomena (from upstream to downstream) and provides a good framework to introduce basin-scale features as a driver for variable dynamics at a wider national scale. Using the flow direction theme to determine the flow accumulation path, an accumulated value is calculated for each cell corresponding to the sum of the variable value for all cells upstream. This method is inherent to the calculation of the flow accumulation theme, and it is not applicable to the cost distance theme, since the nature and influence of this variable is noncumulative. Therefore it was only applied to the flow number and, because this variable should be representative of soil permeability conditions at a basin scale, the calculated accumulated value for each cell corresponded to the mean of all upstream cells instead of the sum.

As stated above, the selection of variables and respective data sets was based on three criteria: (a) ability to incorporate parameters influent in both progressive and flash floods;

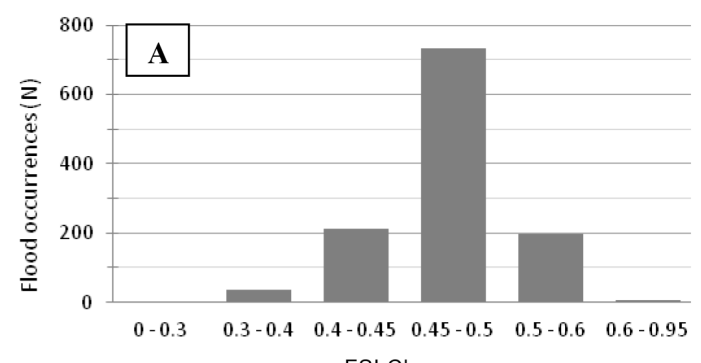

FSI Classes

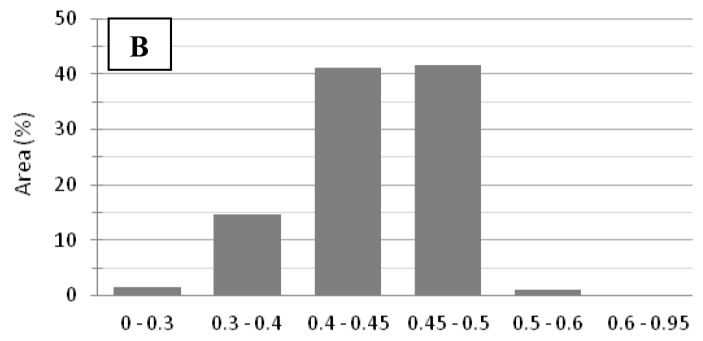

FSI Classes

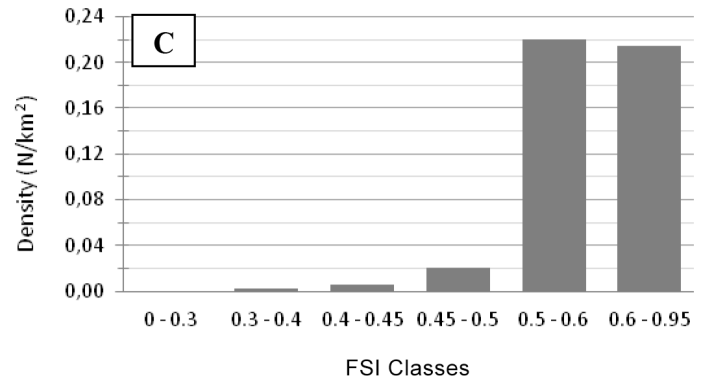

Figure 6. Relationship between the FSI classes and the spatial distribution of DISASTER occurrences (1865-2010) in mainland Portugal: (a) occurrence frequency per class $(\mathrm{N}),(\mathbf{b})$ frequency of each FSI class (area in percentage) and (c) occurrence density $\left(\mathrm{N} \mathrm{km}^{-2}\right)$ per FSI class.

(b) minimizing number of introduced variables to contribute to index transparency; and (c) data set homogeneity (e.g. origin, spatial resolution) across the Portuguese territory. Three final variables were chosen: (i) flow accumulation (Lehner et al., 2008), (ii) cost distance matrix and (iii) flow number, as illustrated in Fig. 3. The first two describe the potential water accumulation in the riverbed and adjacent areas, while the last assesses soil permeability based on land use and geology.

The definition of variable weights for the final composition of the index was based on an iterative comparison of different weighting results (Reis, 2011) with the 100-year flood inundation area map for the main Portuguese rivers. Different combinations were tested, and the selected weights were the ones which better described the 100-year floodable areas and, at the same time, did not overestimate Alentejo and Algarve regions, due to their general low slope and high river-density network.

The final step to arrive at a flood susceptibility index (FSI) for the Portuguese territory was to define four classes. The 


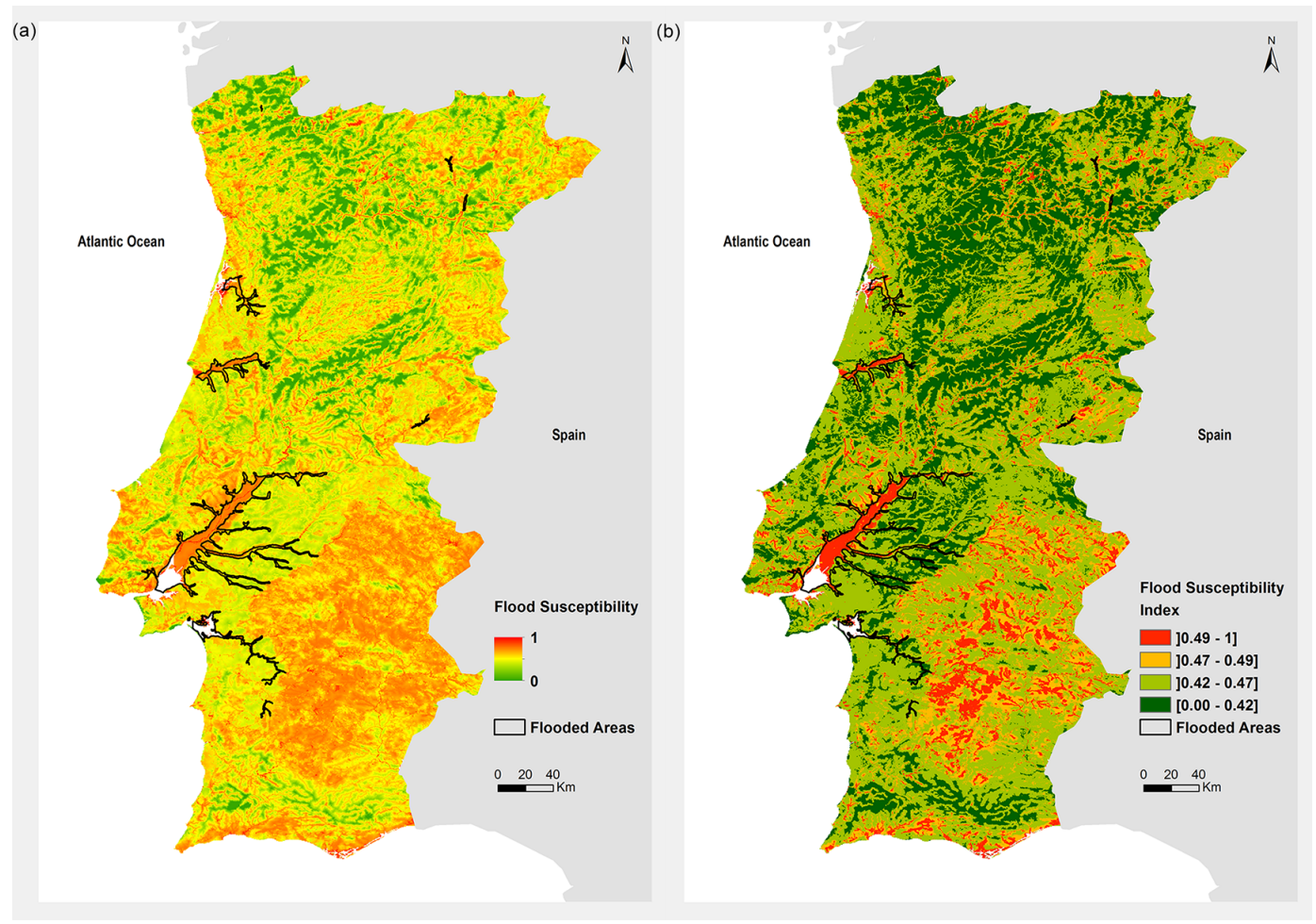

Figure 7. Comparison between the flood susceptibility index values and the limits of the 100-year flood area map data set for the main Portuguese rivers considering (a) a continuous susceptibility scale and (b) the proposed index classes.

definition of those classes was made based on a comparison with the already mentioned 100-year flood area maps and on an empirical analysis of the physical characteristics of the Portuguese territory. This last approach was developed using visual interpretation with experts, adjusting each interval to accomplish a higher agreement.

In order to evaluate the quality of FSI model a further validation was carried out, based on the DISASTER hydrogeomorphologic database. The properties of this database are fully described in Zêzere et al. (2014). However, it should be noted that this database does not contain all detected flood occurrences, only those where people were directly affected (human casualties: dead, missing, wounded, displaced and evacuated). Therefore, the records are coincident with the presence of human constructions and activities, so the floods that occurred outside these areas or that did not have the specified human impacts were not recorded in this database. In this context, the normally used ROC curves for validation proposes are not appropriate for success evaluation of model results.

Additionally, the records have different levels of positional accuracy, so only the records based on precise coordinates, topographic features and identified toponyms (1187 occurrences) were considered for validation, ensuring the necessary spatial accuracy compatible with the resolution $(90 \mathrm{~m})$ used in work.
After FSI classification, the map was crossed with the spatial distribution of flood occurrences for the period 1865 to 2010. Differences in classification process can lead to different interpretations; this fact, together with the specific characteristics of the database and the methodology associated with FSI, requires careful evaluation of the results.

A classification of FSI values in six classes shows that nearly $62 \%$ of the occurrences lie in the 0.45 to 0.5 susceptibility class, as shown in Fig. 6a. Values below 0.3 are not coincident with occurrences and these ones are present residually in class 0.6 to 0.95 (about $0.6 \%$ ). The non-increasing occurrence frequency, from the lowest to the higher susceptibility class, is also associated with differences in class frequency in mainland Portuguese territory, Fig. 6b. The calculation of occurrence densities eliminates the influence of the frequency of each class in the results; thus calculating this density (number of occurrences per $\mathrm{km}^{2}$ ) allows one to accept the results obtained for FSI as representatives for the entire mainland Portugal, as illustrated in Fig. 6c. In fact, the FSI value of 0.5 appears to provide a critical threshold above which the relatively high hazard and the presence of vulnerable elements comes together. Thus, the occurrence density value of the class $0.5-0.6\left(0.22 \mathrm{NO} \mathrm{km}^{-2}\right)$ is 11 times greater than in the previous class $\left(0.02 \mathrm{NO} \mathrm{km}^{-2}\right)$.

The density of events in the class of highest susceptibility (0.6-0.95) remains similar to the previous class value $(0.5-$ 
Table 2. Flood susceptibility index classes.

\begin{tabular}{|c|c|c|c|}
\hline Class & Area characterization & $\begin{array}{l}\text { Index } \\
\text { interval }\end{array}$ & Physical characteristics \\
\hline $\begin{array}{l}4 \\
\text { Very high }\end{array}$ & $\begin{array}{l}\text { Differentiation of main water } \\
\text { lines } \\
\text { Some main urban areas }\end{array}$ & ] $0.49 ; 1]$ & $\begin{array}{l}\text { Water lines and contiguous regions } \\
\text { Regions of impervious soil (e.g. cities) }\end{array}$ \\
\hline $\begin{array}{l}3 \\
\text { High }\end{array}$ & $\begin{array}{l}\text { Differentiation of adjacent } \\
\text { flood plains in the main rivers }\end{array}$ & ]0.47; 0.49] & $\begin{array}{l}\text { Flooding regions associated with large } \\
\text { rivers } \\
\text { Regions of permeable soil } \\
\text { Regions with high water accumulation } \\
\text { potential }\end{array}$ \\
\hline $\begin{array}{l}2 \\
\text { Low }\end{array}$ & $\begin{array}{l}\text { Areas with increasing distance } \\
\text { to water courses and steeper } \\
\text { slopes }\end{array}$ & ]0.42; 0.47] & $\begin{array}{l}\text { Regions of medium/low water } \\
\text { accumulation } \\
\text { Regions with significant water transport } \\
\text { cost distance values } \\
\text { Regions of permeable soil }\end{array}$ \\
\hline $\begin{array}{l}1 \\
\text { Very low }\end{array}$ & $\begin{array}{l}\text { Mountainous areas or with no } \\
\text { water courses in their vicinity }\end{array}$ & {$[0 ; 0.42]$} & $\begin{array}{l}\text { Regions with no water accumulation } \\
\text { potential } \\
\text { Regions with higher soil permeability } \\
\text { Regions with very high water transport } \\
\text { cost distance values }\end{array}$ \\
\hline
\end{tabular}

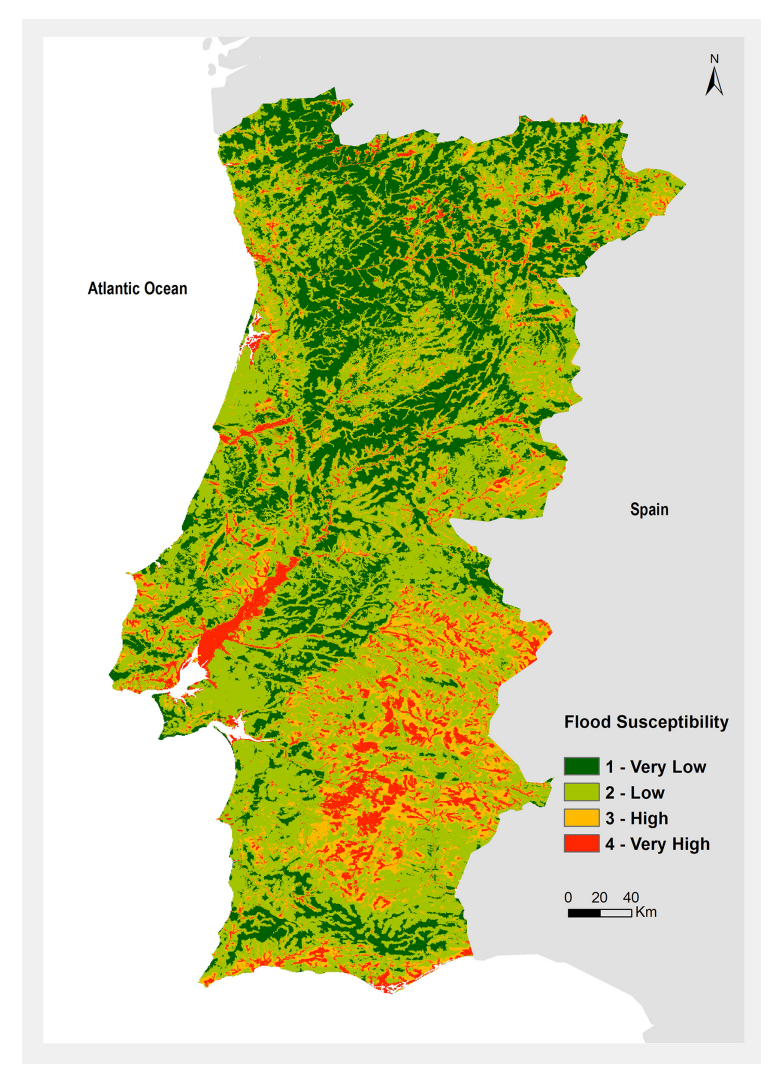

Figure 8. Flood susceptibility index.
0.6), and even a small decrease can be observed that reverses the growing trend along the remaining classes. This is perfectly explainable through the people perception regarding flood hazard: although the areas classified with FSI values above 0.6 are in fact the most dangerous by the frequency and magnitude of floods, this behaviour is apprehended and remains in memory of local populations that avoid the most dangerous places within these areas. In this context it is relevant that the class $0.5-0.6$ coincides largely with the presence of flash floods and contains almost all the dead and wounded occurrences, while the class 0.6-0.95 essentially coincide with the occurrence of fluvial floods, where the dead and wounded are almost absent, but on the contrary the evacuated and temporarily displaced persons situation are predominant.

\subsection{Results and discussion}

Since the first two methodological steps presented in the previous section refer only to intermediary preprocessing tasks, only the analysis of the different index composition stages and its respective validation procedure are included in this section.

The final variable weights for the composition of the FSI, obtained after comparison with flood area maps for the main rivers and expert consultation, heighten the importance of flow accumulation (0.47) and cost distance (0.36), which have a combined weight of 0.83 , when related to the flow number (0.17). This fact points towards a possible higher sensitivity of the index to overflow processes usually associated with fluvial floods in comparison to superficial flow gen- 

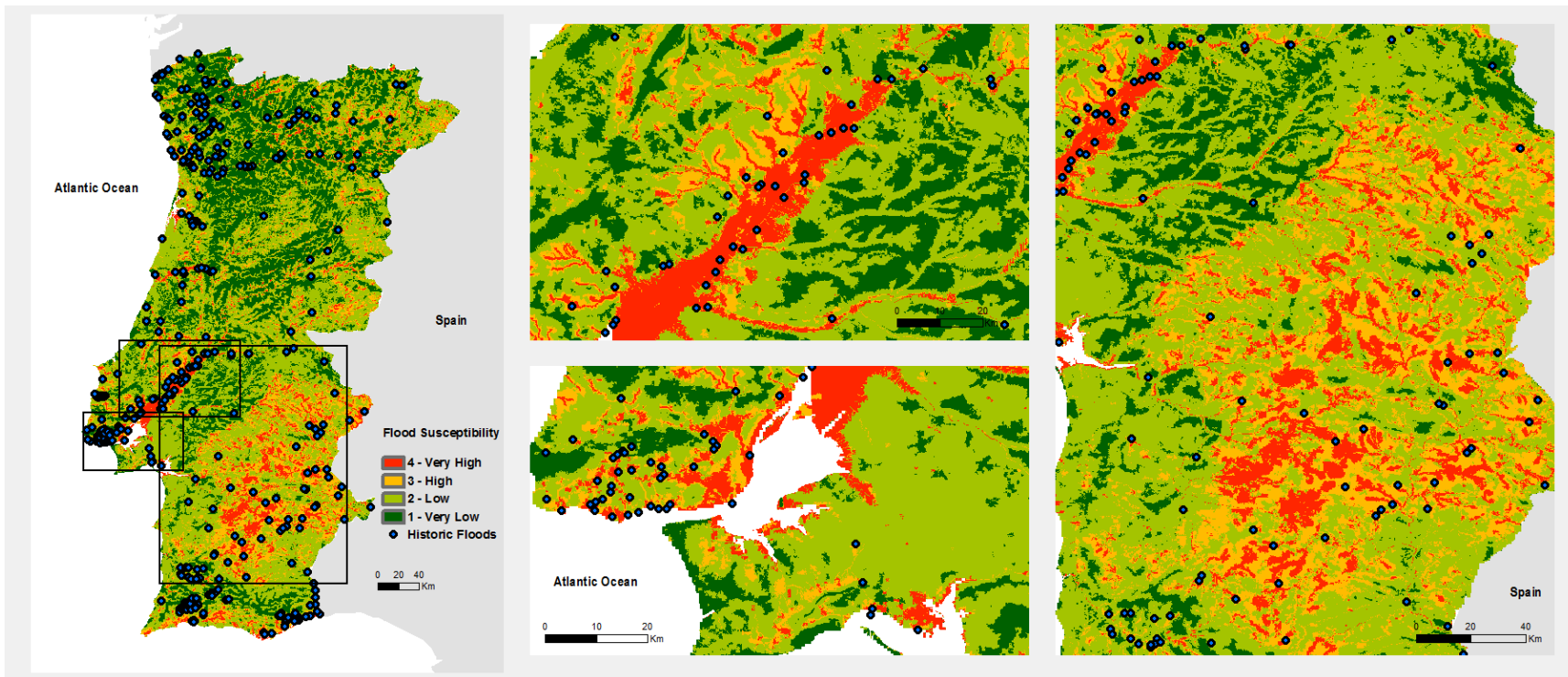

Figure 9. Comparison of the flood susceptibility index with the flood events map provided by the Water Institute for (a) Portugal, (b) Tagus Basin, (c) cities of Lisbon and Setúbal, and (d) Alentejo region.

eration processes that, although also influence in this flood type, are more determinant in flash floods, especially in impermeable urban areas. This will be further investigated during the validation process.

Regarding the definition of the susceptibility classes, the visual analysis of the range of original susceptibility values present inside and outside the limits defined by the 100-year flood area map for the main Portuguese rivers allowed an accurate assessment of the two higher classes. In fact, most of the values included in those classes are within the limits of those flooded areas. As can be seen in Fig. 7, the adjacent areas to all major and medium-sized rivers in the Portuguese territory are also included in these higher classes. This demonstrates the FSI ability to better identify regions susceptible to fluvial floods in the highest class (see Sect. 3.4) due, as stated above, to the higher importance given to the flow accumulation and cost distance variables.

The definition of the remaining classes was made by visual interpretation of the spatial distribution of the index values when compared with maps of the original variables, such as the Hydrosheds DEM, slope and land use. All information related to the final set of classes is given in Table 2.

It should be noted that this susceptibility class definition methodology led to unequal interval ranges for the different classes, as can be seen in the third column of Table 2 . This was somewhat expected since it was improbable that an index composed of three linearly normalized and combined variables could translate flood susceptibility in a regular scale. In fact, the variation of influence of each of those variables in flooding processes is, in most cases, non-linear and therefore is associated with very different interval ranges. Therefore their combination would most probably lead, as it was confirmed by this work, to susceptibility classes defined by heterogeneous intervals. Moreover, some of the input variables also have very unbalanced normalized value distributions, namely flow accumulation (high frequency of low values and a few very high values) and cost distance (mostly high values), further distorting the distribution of the final susceptibility values and consequently the definition of the corresponding classes.

In addition to the above-mentioned main rivers (Fig. 8), FSI for the Portuguese territory also identifies some major cities like Lisbon, Coimbra, Aveiro, Setúbal, Faro and Oporto and some small basin areas in the south part of Portugal (Algarve) as highly susceptible to floods (classes 3 and 4). This showcases the index sensitivity to identify also flash-floodprone areas, characterized by highly impermeabilized artificial surfaces situated in plain regions in the vicinity of relevant water courses, as illustrated in Fig. $9 \mathrm{~b}$ and c. The Alentejo region, east of Lisbon, Fig. 9a, is also classified as highly susceptible (class 3 ) due to its topographical and geological characteristics, since most of the territory is plains, with a high hydrographic network density and impermeable rocky (shale and marble) or clay soils.

In the lower susceptibility classes is possible to find the following:

a. the more mountainous regions like Serra da Estrela, in the centre of Portugal, between Coimbra and Guarda and some of the northeast of Portugal;

b. areas with highly permeable sandy soils, such as the south part of the Tagus and Sado basins and most of the coastal area between Lisbon and Aveiro; or 
c. combining both those characteristics, in the north central part of Portugal and northern part of Algarve.

Validation of the Portuguese FSI against the flood events point data set provided by the Water Institute showed a general good direct correspondence between the frequency of flood points and the magnitude of susceptibility values in the vicinity of those points, as illustrated in Fig. 7a. Looking in greater detail the index confirmed its ability to capture (a) a higher flood susceptibility associated with the main Portuguese rivers and their adjacent areas (example given for the Tagus basin in Fig. 9b) and (b) flash-flood-prone urban areas like Lisbon and Setúbal, as illustrated in Fig. 9c.

In the case of Alentejo, while some flood points can be found along the rivers Guadiana and Sado and some of their tributaries, there is an apparent overall inconsistency between the high flood susceptibility values and the corresponding number of flood points. This arises from the nature of the index, which reflects the flood propensity associated with terrain characteristics and excludes flow or precipitation quantitative information. Since, although dense, most of the hydrographic network in Alentejo is characterized by a low flow regime with a high seasonal variation, driven by low mean annual precipitation, this artifact is to be expected.

Finally the flood data set compiled by Quaresma (2008), representing the number of high-magnitude flood events per municipality in the last century, Fig. 4b, shows a good correspondence between the spatial variation in both data sets, particularly in the Tagus basin and in the Lisbon and Oporto regions. Nevertheless the inconsistency in the Alentejo region is also visible in the comparison with this flood map. It should be noted that both validation data sets used in this analysis have a bias towards more densely populated areas since they are compiled from information gathered in journals and civil protection registries and misrepresent flood occurrence in rural and natural areas with lower human presence.

\section{Conclusions}

The development of a national flood susceptibility index entails several challenges related to difficulties in capturing the different flood dynamics usually occurring in a wide territory across different spatial scales. The work presented here presents a first attempt to implement this type of index for the Portuguese continental territory.

The first results are very promising with a consistent representation of the overall spatial distribution of flood susceptibility. The presented methodological approach addresses some of those scale issues by applying a spatial aggregation methodology that better characterizes the cumulative influence of the different variables across spatial scales (from cell to basin and higher). Furthermore the selection of only three variables that represent water accumulation potential, topography and soil permeability allowed for a clear interpretation of the index and an apprehension of different flooding phenomena, ranging from fluvial floods in large rivers to urban flash floods.

Nevertheless some possible overestimation of flood susceptibility in regions of low precipitation was observed and should be addressed in future work by including appropriate precipitation data sets such as interpolated ground station precipitation for different return periods and durations (Brandão et al., 2001). Other developments to be implemented in the future will be focused on improving the representation of the higher susceptibility associated with smaller basins or with stepper slopes due to a higher superficial flow generation potential and smaller concentration times. In the future, this could be overcome by the inclusion of two themes containing spatially aggregated values of slope (accumulated mean) and concentration time (accumulated sum), following the methodology used in this work.

Future work will also include the following: (a) the minimization of possible index distortion and subjectivity in the definition of the final susceptibility classes using reclassified variables, according to their influence in susceptibility, instead of a continuous scale; (b) the optimization of the variable weight definition process based on the work of Kouriagalas and Karazas (2011); and (c) the inclusion of more robust national flood validation data sets compiled from flood insurance data and more accurate civil protection registries.

Acknowledgements. We acknowledge (a) Hugo Costa, Ângela Antunes and Professor Filipe Duarte Santos, also part of CIRAC Project technical team, for their contributions in the discussions and GIS layouts and (b) APS - Portuguese Association of Insurers, who funded the project.

Edited by: V. Artale

Reviewed by: L. Marchi and one anonymous referee

\section{References}

Adger, W. N.: Vulnerability, Global Environmental Change, 16, 268-281, 2006.

Ascenso, V. P.: Análise de Ocorrência de Cheias e Deslizamentos de Vertente no Concelho da Batalha, Msc Thesis, Departamento de Geografia da Faculdade de Letras Lisboa, Universidade de Lisboa, Portugal, 133 pp., availabe at: http://repositorio.ul. pt/bitstream/10451/5956/1/igotul001414_tm.pdf (last access: 30 July 2015), 2011.

Balica, S. F., Wright, N. G., and van der Meuden, F.: A Flood vulnerability index for coastal cities and its use in assessing climate change impacts, Nat. Hazards, 64, 73-105, doi:10.1007/s11069012-0234-1, 2012.

Brandão, C., Rodrigues, R., and Costa, J. P.: Análise de Fenómenos Extremos Precipitações Intensas em Portugal Continental, Direção dos Serviços de Recursos Hídricos, Lisboa, available at: http://www.isa.utl.pt/der/Hidrologia/relatorio_prec_ intensa.pdf (last access: 30 July 2015), 2001. 
Collier, C. G. and Fox, N. I.: Assessing the flooding susceptibility of river catchments to extreme rainfall in the United Kingdom, International Journal of River Basin Management, 1, 225-235, doi:10.1080/15715124.2003.9635209, 2003.

Cutter, S. L., Barnes, L., Berry, M., Burton, C., Evans; E., Tate, E., and Webb, J.: Community and Regional Resilience: Perspectives from hazards, disasters, and emergency management - CARRI Research Report 1, Hazards and Vulnerability Research Institute, Department of Geography, University of South Carolina, Columbia, South Carolina, , 19 pp., 2008.

De Roo, A., Barredo, J., Lavalle, C., Bodis, K., and Bonk, R.: Potential Flood Hazard and Risk Mapping at Pan-European Scale. Book Chapter - Digital Terrain Modelling, Lecture Notes in Geoinformation and Cartography, edited by: Jordan, G., Springer Berlin Heidelberg, Earth and Environmental Science, ISBN978-3-540-36731-4, doi:10.1007/978-3-540-367314_8, 183-202, 2007.

EEA: Urban adaptation to climate change in Europe, Challenges and opportunities for cities together with supportive national and European policies, EEA Report No 2/2012, European Environment Agency, ISBN978-93-9213-308-5, Copenhagen, Denmark, 143 pp., 2012a.

EEA: Climate change, impacts and vulnerability in Europe 2012, EEA Report No 12/2012, European Environment Agency, ISBN978-92-9213-346-7, Copenhagen, Denmark, 253 pp., 2012b.

Figueiredo, E., Valente, S., Coelho, C., and Pinho, L.: Coping with Risk - Analysis on the importance of integrating social perceptions on flood risk into management mechanisms - the case of the municipality of Águeda, Portugal, J. Risk Res., 12, 581-602, doi:10.1080/13669870802511155, 2009.

Instituto do Ambiente: CORINE Land Cover 2000 em Portugal, Relatório Técnico, available at: http://sniamb.apambiente.pt/ (last access: 30 July 2015), 2005.

IPCC: Managing the Risks of Extreme Events and Disasters to Advance Climate Change Adaptation, in: A Special Report of Working Groups I and II of the Intergovernmental Panel on Climate Change, edited by: Field, C. B., Barros, V., Stocker, T. F., Qin, D., Dokken, D. J., Ebi, K. L., Mastrandrea, M. D., Mach, K. J., Plattner, G.-K., Allen, S. K., Tignor, M., and Midgley, P. M., Cambridge University Press, Cambridge, New York, USA, 582 pp., ISBN978-1-107-02506-6, 2012.

Jacinto, R., Cruz, M. J., and Santos, F. D.: Development of water use scenarios as a tool for adaptation to climate change, Drink. Water Eng. Sci., 6, 61-68, doi:10.5194/dwes-6-61-2013, 2013.

Kourgialas, N. N. and Karatzas, G. P.: Flood Management and a GIS modelling method to assess flood-hazard areas- a case study, Hydrolog. Sci. J., 56, 212-225, doi:10.1080/02626667.2011.555836, 2011.

Lehner, B., Verdin, K., and Jarvis, A.: HydroSheds Technical Documentation, Version 1.1., http://hydrosheds.cr.usgs.gov (last access: 30 July 2015), 2008.

Lobo-Ferreira, J. P. C.: Inventariando, Monitorizando e Gerindo de Forma Sustentável Recursos Hídricos Subterrâneos, LNEC, Lisboa, available at: https://www.researchgate.net/publication/ 266878225 (last access: 30 July 2015), 1995.

Marchi, L., Borga, M., Preciso, E., and Gaume, E.: Characterisation of selected extreme flash floods in Europe and impli- cations for flood risk management, J. Hydrol., 394, 118-133, doi:10.1016/j.jhydrol.2010.07.017, 2010.

Quaresma, I.: Inventariação e Análise de Eventos HidroGeomorfologicos com carácter danoso em Portugal Continental, Msc Thesis, Departamento de Geografia da Faculdade de Letras Lisboa, University of Lisbon, Portugal, 100 pp., 2008.

Quaresma, I. and Zêzere, J. L.: Cheias e movimentos de massa com carácter danoso em Portugal Continental. Santos, N.; Cunha, L. (coord.), Trunfos de uma Geografia Activa, Desenvolvimento Regional, Ordenamento e Tecnologia, Imprensa da Universidade de Coimbra, Coimbra, Portugal, 799-807, ISBN978-98926-0111-3, 2011.

Ramos, C. and Reis, E.: As Cheias no Sul de Portugal em Diferentes Tipos de Bacias Hidrográficas, Finisterra, XXXVI, 61-82, ISSN0430-5027, Lisbon, 2001.

Ramos, C. and Reis, E.: Floods in Southern Portugal: their physical and human causes, Impacts and Human response, Mitigation and Adaptation Strategies for Global Change, 7, 267-284, Kluwer Academic Publishers, the Netherlands, 2002.

Ramos, C., Reis, E., and Zêzere, J. L.: Reserva Ecológica Nacional do Oeste e Vale do Tejo - Anexo 4 Zonas Ameaçadas pelas Cheias (ZAC) e pelo mar (ZAM), Quadro de Referência Regional da Reserva Ecológica Nacional do Oeste e Vale do Tejo, Comissão de Coordenação e Desenvolvimento Regional do Oeste e Vale do Tejo, available at: http://www.ccdr-lvt.pt/pt/areas-de-ren\T1 textemdashquadro-de-referencia-regional/1913.htm (last access: 30 July 2015), 2009.

Ramos, C., Reis, E., and Zêzere, J. L.: Reserva Ecológica Nacional da Área Metropolitana de Lisboa - Anexo 4 Zonas Ameaçadas pelas Cheias (ZAC) e pelo Mar (ZAM), Quadro de Referência Regional da Reserva Ecológica Nacional do Oeste e Vale do Tejo. Comissão de Coordenação e Desenvolvimento Regional do Oeste e Vale do Tejo, http://www.ccdr-lvt.pt/pt/areas-de-ren\T1 textemdashquadro-de-referencia-regional/1913.htm (last access: 30 July 2015), 2010.

Reis, E.: Análise de bacias hidrográficas, susceptibilidade à ocorrência de cheias e Sistemas de Informação Geográfica: da definição do quadro conceptual até à proposta de um modelo de avaliação, VIII Congresso da Geografia Portuguesa, Repensar a Geografia para Novos Desafios, Comunicações, Lisboa, Portugal, 1-6, 2011.

Sá, L. and Vicêncio, H.: Risco de Inundações - Uma Metodologia para a sua Cartografia, Territorium, 18, 227-230, available at: http://www.uc.pt/fluc/nicif/riscos/Documentacao/ Territorium/T18_artg/Luis_Sa.pdf (last access: 30 July 2015), 2011.

Santangelo, N., Santo, A., Di Crescenzo, G., Foscari, G., Liuzza, V., Sciarrotta, S., and Scorpio, V.: Flood susceptibility assessment in a highly urbanized alluvial fan: the case study of Sala Consilina (southern Italy), Nat. Hazards Earth Syst. Sci., 11, 2765-2780, doi:10.5194/nhess-11-2765-2011, 2011.

USSCS: United States Department of Agriculture, Soil Conservation Service, Urban Hydrology for Small Watersheds, Technical Release No. 55, 2nd Edition, Washington, DC, 164 pp., 1986.

Verde, J. and Zêzere, J. L.: Avaliação da Perigosidade de Incêndio Florestal, VI Congresso da Geografia Portuguesa, Lisbon, Portugal, 17-20 October 2007, 23, available at: http://riskam.ul.pt/images/pdf/comlivactnac_2007_ 
perigosidade_incendio_florestal.pdf (last access: 16 August 2015), 2007.

Yahaya, S., Ahmad, N., and Abdalla, R.: Multicriteria Analysis for Flood Vulnerable areas in Hadejia-Jama' are River Basins, Nigeria, Eur. J. Sci. Res., ISSN1450-216X, 42, 71-83, 2010.

Zêzere, J. L., Pereira, A. R., and Morgado, P.: Perigos Naturais e Tecnológicos no Território de Portugal Continental. X Coloquio Ibérico de Geografia, Évora, Universidade de Évora, Portugal, 17 pp., 2005.
Zêzere, J. L., Pereira, S., Tavares, A., Bateira, C., Trigo, R., Quaresma, I., Santos, P., Santos, M., and Verde, J.: DISASTER: a GIS database on hydro-geomorphologic disasters in Portugal, Natural Hazards, 71, 1029-1050, doi:10.1007/s11069-013-1018y, 2014. 